\title{
A Study on the Relationship between Carotid Artery Intima-Media Thickness and Clinical Chemistry Tests
}

\author{
Dae-Sik Kim ${ }^{1}$, Hyun-Ho Sung ${ }^{1}$, Eun-kyung $\mathrm{Cho}^{1}$, and Jong-Woo Lee ${ }^{2}$ \\ ${ }^{1}$ Department of Clinical Laboratory Science, Dongnam Health University, Suwon 16328, Korea \\ ${ }^{2}$ Department of Laboratory Medicine, Korea University Ansan Hospital, Ansan 15355, Korea
}

\section{경동맥 초음파 결과와 임상화학 검사의 상관성 연구}

\author{
김대식 ${ }^{1}$, 성현호 $^{1}$, 조은경 ${ }^{1}$, 이종우 $^{2}$ \\ ${ }^{1}$ 동남보건대학교 임상병리과, ${ }^{2}$ 고려대학교 안산병원 진단검사의학과
}

\begin{abstract}
Carotid Intima-Media Thickness (CIMT) testing is a test that precisely assesses cerebrovascular and coronary heart diseases. According to many previous studies, CIMT predicts atherosclerosis and is highly correlated to cardiovascular disease risk factors. It has also been reported that CIMT is an independent predictor of risk factors for myocardial infarction and stroke. Therefore, the purpose of this study is to investigate CIMT and other independent factors through a correlation study with the clinical laboratory test results of a blood test. As a result, this study could not prove the correlation between CIMT and risk factors of cardiovascular disease (TC, TG, LDL cholesterol, and HDL cholesterol) due to an insufficient number of subjects. Nevertheless, a positive correlation was demonstrated between CIMT and ALT ( $p<0.05)$, GGT ( $p<0.05)$, Uric acid $(p<0.05)$, and CEA $(p<0.05)$ at a statistically significant level, suggesting a continuation of the study.
\end{abstract}

Keywords: Carotid artery intima-media thickness (CIMT), Clinical chemistry

This is an Open Access article distributed under the terms of the Creative Commons Attribution Non-Commercial License (http://creativecommons.org/licenses/by-nc/4.0) which permits unrestricted non-commercial use, distribution, and reproduction in any medium, provided the original work is properly cited.

Copyright (C) 2015 The Korean Society for Clinical Laboratory Science. All rights reserved.
Corresponding author: Hyun-Ho Sung Department of Clinical Laboratory Science, Dongnam Health University, Suwon 16328 Korea

Tel: 82-31-249-6414

E-mail:wantyou7@dongnam.ac.kr

Received: October 14, 2015

Revised: October 30, 2015 Accepted: November 9, 2015

\section{Introduction}

Carotid Artery Ultrasonography is a test that accurately assesses cerebrovascular and coronary heart diseases through measuring the Carotid Intima-Media Thickness (CIMT) and is a simpler, faster, and safer test compared to Computed Tomography (CT) or Magnetic Resonance Imaging (MRI) (Salonen et al., 1990). The carotid is composed of intima, media, and adventitia, and generally the thickness of the intima and media in the inner side of the adventitia with higher brightness are measured. CIMT of a normal person is different by race, gender, and age. According to a prospective domestic study in 2004 that investigated 470 subjects, the average CIMT of a healthy adult was $0.63 \pm 0.11 \mathrm{~mm}$ on the right and $0.64 \pm 0.11 \mathrm{~mm}$ on the left, and the average CIMT of an adult with hypertriglyceridemia and hypertension was $0.70 \pm 0.13 \mathrm{~mm}$ on the right and $0.71 \pm 0.14 \mathrm{~mm}$ on the left (Bae et al., 2005). In general, standard CIMT of a normal person is set as less than $0.7 \mathrm{~mm}$ in clinical setting, and it was reported that a $0.1 \mathrm{~mm}$ increase of CIMT follows with 10 5\% increase of myocardial infarction, and 13 18\% increase of stroke (Freedman et al., 2004). CIMT is used as an indicator for early prediction of cardiovascular diseases, as it has an interrelationship with cardiovascular risk factors such as age, 
male, obesity, hypertension, hyperlipidemia, diabetes, and smoking (Burke et al., 1995). Among the individual risk factors of cardiovascular diseases, total cholesterol, HDL-cholesterol, LDL-cholesterol, and triglyceride are blood test categories that are commonly used to evaluate hyperlipidemia (Chambless et al., 1997). In modern days, many people take advantage of health check-ups for early detection and treatment of diseases. Moreover, South Korea has been providing free health check-ups, including general health check-up, cancer screening, and health check-up for infants based on the Framework Act on Health Examination that was established on March 21st, 2008, to the public after establishing the National Health Insurance Law on December 31st, 1997 (Sung, 2014). Based on this setting, this study aimed to investigate the relationship between the various blood test items that are generally included in the national health check-up category and CIMT by ultrasonography, which is not included in the basic health check-up category.

\section{Materials and Methods}

\section{Subjects}

A total of 47 healthy adults in the age of 30 55 were investigated through carotid ultrasonography and clinical laboratory blood test at a large comprehensive health examination center located in the southern part of Gyeonggi-do in 2014. Subjects were grouped into the category of 30's for age $30 \sim 40,40$ 's for $41 \sim 50$, and 50's for $51 \sim 55$.

\section{Anthropometric data and blood test}

An automatic anthropometric instrument that measures the height and weight at the same time was used. Body Mass Index (BMI) was calculated using the SPSS statistical package by dividing weight by height squared and was treated as a variable. Blood test was performed by collecting venous blood samples after fasting for more than 8 hours, and Aspartate aminotransferase (AST), Alanine Aminotransferase (ALT), Alkaline phosphatase (ALP), Gamma( $\gamma$ )-glutamyl transpeptidase (GGT), Total bilirubin (T-Bil), Uric acid, Total Cholesterol (TC), High density lipoprotein cholesterol (HDL), Low density lipoprotein cholesterol (LDL), Triglyceride (TG),
Lactate dehydrogenase (LDH), Creatine Phosphokinase (CPK), and carcinoembryonic antigen (CEA) were tested. Blood test were measured using Hitachi 7180 (Hitachi, Japan).

\section{Carotid ultrasonography test}

CIMT was measured using Accuvix V20 (Medison, South Korea) on 3 parts: the common carotid, the carotid bulb (Bulb), and the area in between the two. Study subjects were facing the left side and laid down comfortably to set the probe around the central part of the sternocleidomastoid, which is below the thyroid cartilage. The probe was manipulated vertically to show the cross section of the vein (internal jugular) and artery (common carotid) on the screen of Accuvix V20 and horizontally for the longitudinal side of the vein and artery. The angle of the probe was slightly inclined towards the back of the neck to check the absence of the vein and presence of the common carotid artery and the oral region on the screen. A dot was marked on the starting point of the dark area of the intima-media and end point of the bright area and CIMT was measured in mm.

\section{Statistical analysis}

Statistical analysis was performed using the SPSS, PC, Version 21.0 (SPSS Inc., Chicago, IL, USA) program. A frequency analysis and mean (M) and standard deviation (SD) were calculated for the physical features, blood test results, and CIMT of the subjects. An independent t-test was performed for homogeneity test, and ANOVA test for the difference, Post-test was used for Dunnett 3 ways and a correlation analysis was performed for relational analysis. All statistical significance level was set as $p<0.05$.

\section{Results}

\section{General characteristics of subjects}

The total number of subjects who participated in this study is 67 with 35 males and 32 females. The average age of the subjects was $45.64 \pm 5.05$, showing a difference $(p<0.01)$ between $47.00 \pm 4.70$ for male and $44.16 \pm 5.98$ for female. There was a difference $(p<0.01)$ in weight with $73.72 \pm 8.55$ $\mathrm{kg}$ for males and $56.38 \pm 8.19 \mathrm{~kg}$ for females. The average BMI 
for males was $24.97 \pm 2.30$ and $24.17 \pm 12.05$ for females, showing no significant difference between the male and female group. The average systolic blood pressure was $120.34 \pm 13.96 \mathrm{mmHg}$ in males and $108.47 \pm 12.51 \mathrm{mmHg}$ in females, showing a statistically significant difference $(p<$ 0.01 ) between the groups. The average diastolic blood was $81.43 \pm 9.61 \mathrm{mmHg}$ in males and $70.97 \pm 10.31 \mathrm{mmHg}$ in females, displaying a significant difference $(p<0.01)$. The general characteristics of the subjects are described on Table 1.

\section{Clinical laboratory test results by gender}

Clinical laboratory test result by gender showed a significant difference $(p<0.01)$ between $31.57 \pm 14.18 \mathrm{IU}$ in the male group and $19.72 \pm 5.68 \mathrm{IU}$ in the female group, with the male group displaying a higher average value. The average ALT was higher in the male group, showing a significant difference $(p<0.01)$ between $32.89 \pm 18.00 \mathrm{IU}$ in males and $15.34 \pm 7.23$ in females. The average GGT was higher in the male group, showing a significant difference $(p<$ 0.01 ) between $74.89 \pm 62.05 \mathrm{IU}$ in males and $17.16 \pm 10.74 \mathrm{IU}$ in females. ALP was higher in the male group, showing a significant difference $(p<0.01)$ between $59.63 \pm 17.94 \mathrm{IU}$ in males and $49.56 \pm 10.38 \mathrm{IU}$ in females. Total bilirubin was higher in the male group, showing a significant difference $(p<$ 0.01 ) between $1.48 \pm 1.17 \mathrm{mg} / \mathrm{dL}$ in males and $0.87 \pm 0.27$ $\mathrm{mg} / \mathrm{dL}$ in females. Uric acid was higher in the male group ( $p<$ 0.01 ) with $6.23 \pm 1.22 \mathrm{mg} / \mathrm{dL}$ in males and $4.06 \pm 0.95 \mathrm{mg} / \mathrm{dL}$ in females. Total cholesterol was higher in the male group,

Table 1. General characteristics of subjects

\begin{tabular}{lcccc}
\hline & Total & Male & Female & $\mathrm{N}=32$ \\
Character & $\mathrm{N}=67$ & $\mathrm{~N}=35$ & $\mathrm{~F} / \mathrm{t}$ \\
\cline { 2 - 4 } & & $\mathrm{M} \pm \mathrm{SD}$ & $1.08 / 2.17^{\star}$ \\
Age & $45.64 \pm 5.50$ & $47.00 \pm 4.70$ & $44.16 \pm 5.98$ & $1.74 / .19^{\dagger}$ \\
Height $(\mathrm{cm})$ & $165.86 \pm 8.66$ & $172.09 \pm 5.81$ & $159.03 \pm 5.52$ & $.76 / 8.45^{\dagger}$ \\
Weight $(\mathrm{kg})$ & $65.44 \pm 12.05$ & $73.72 \pm 8.55$ & $56.38 \pm 8.19$ & $2.79 / .38$ \\
BMl $\left(\mathrm{kg} / \mathrm{m}^{2}\right)$ & $24.59 \pm 8.43$ & $24.97 \pm 2.30$ & $24.17 \pm 12.05$ & $.11 / 3.65^{\dagger}$ \\
SBP $(\mathrm{mmHg})$ & $114.67 \pm 14.48$ & $120.34 \pm 13.96$ & $108.47 \pm 12.51$ & $.57 / 4.29^{\dagger}$ \\
DBP $(\mathrm{mmHg})$ & $76.43 \pm 11.19$ & $81.43 \pm 9.61$ & $70.97 \pm 10.31$ & .37 \\
\hline
\end{tabular}

Abbreviation: BMI, body mass index; SBP, systolic blood pressure; $\mathrm{DBP}$, diastolic blood pressure.

${ }^{\star} p<0.05,{ }^{\dagger} p<0.01$.

Table 2. Results of blood test by gender

\begin{tabular}{|c|c|c|c|c|}
\hline \multirow[t]{2}{*}{ Variable } & $\begin{array}{l}\text { Total } \\
\mathrm{N}=67\end{array}$ & $\begin{array}{l}\text { Male } \\
\mathrm{N}=35\end{array}$ & $\begin{array}{c}\text { Female } \\
N=32\end{array}$ & \multirow[t]{2}{*}{$F / t$} \\
\hline & \multicolumn{3}{|c|}{$\mathrm{M} \pm \mathrm{SD}$} & \\
\hline AST (IU/L) & $25.91 \pm 12.42$ & $31.57 \pm 14.18$ & $19.72 \pm 5.68$ & $18.66 / 4.41^{\dagger}$ \\
\hline ALT (IU/L) & $24.51 \pm 16.41$ & $32.89 \pm 18.00$ & $15.34 \pm 7.23$ & $11.94 / 5.14^{\dagger}$ \\
\hline $\operatorname{ALP}(\mathrm{U} / \mathrm{L})$ & $54.82 \pm 15.55$ & $59.63 \pm 17.94$ & $49.56 \pm 10.38$ & $4.74 / 2.78^{\dagger}$ \\
\hline GGT (U/L) & $47.31 \pm 53.68$ & $74.89 \pm 62.05$ & $17.16 \pm 10.74$ & $31.21 / 5.18^{\dagger}$ \\
\hline T.Bil (mg/dL) & $1.19 \pm 0.91$ & $1.48 \pm 1.17$ & $0.87 \pm 0.27$ & $5.79 / 2.83^{\dagger}$ \\
\hline Uric acid (mg/dL) & $5.19 \pm 1.54$ & $6.23 \pm 1.22$ & $4.06 \pm 0.95$ & $1.77 / 8.15^{\dagger}$ \\
\hline T.Cho (mg/dL) & $196.07 \pm 31.26$ & $203.46 \pm 31.91$ & $188.00 \pm 28.89$ & $0.28 / 2.07^{\star}$ \\
\hline HDL-Cho (mg/dL) & $51.16 \pm 11.83$ & $46.66 \pm 12.11$ & $56.09 \pm 9.43$ & $3.68 /-3.53^{\dagger}$ \\
\hline LDL-Cho (mg/dL) & $122.49 \pm 34.54$ & $126.66 \pm 41.28$ & $117.94 \pm 25.10$ & $10.59 / 1.03$ \\
\hline $\mathrm{TG}(\mathrm{mg} / \mathrm{dL})$ & $153.64 \pm 136.62$ & $212.83 \pm 165.08$ & $88.91 \pm 39.64$ & $25.81 / 4.14^{\dagger}$ \\
\hline LDH (IU/L) & $383.57 \pm 78.71$ & $415.77 \pm 90.35$ & $348.34 \pm 42.26$ & $12.98 / 3.85^{\dagger}$ \\
\hline CPK (IU/L) & $200.97 \pm 570.21$ & $327.12 \pm 784.70$ & $70.88 \pm 34.99$ & $8.38 / 1.85$ \\
\hline CEA (ng/mL) & $1.18 \pm 0.41$ & $1.30 \pm 0.53$ & $1.04 \pm 0.13$ & $40.35 / 2.77^{\dagger}$ \\
\hline
\end{tabular}

Abbreviation: AST, aspartate aminotransferase; ALT, alanine aminotransferase; ALP, alkaline phosphatase; GGT, gamma( $\gamma$ )-glutamyl transpeptidase; T-Bil, total bilirubin; T.Cho, total cholesterol; HDL-Cho, high density lipoprotein cholesterol; LDL-Cho, low density lipoprotein cholesterol; TG, triglyceride; LDH, lactate dehydrogenase; CPK, creatine phosphokinase; CEA, carcinoembryonic antigen. ${ }^{*} p<0.05,{ }^{\dagger} p<0.01$. 
showing a significant difference $(p<0.05)$ between $203.46 \pm$ $31.91 \mathrm{mg} / \mathrm{dL}$ in males and $188.00 \pm 28.89 \mathrm{mg} / \mathrm{dL}$ in females. On the contrary, males and females showed a statistically significant difference $(p<0.01)$ in HDL cholesterol where females showed higher level of HDL cholesterol with an average of $56.09 \pm 9.43 \mathrm{mg} / \mathrm{dL}$ than males with an average of $46.66 \pm 12.11 \mathrm{mg} / \mathrm{dL}$. The male and female group showed a statistically significant difference $(p<0.01)$ in triglyceride level, with an average of $212.83 \pm 165.08 \mathrm{mg} / \mathrm{dL}$ in males and $88.91 \pm 39.64 \mathrm{mg} / \mathrm{dL}$ in females. Males and females showed a statistically significant difference $(p<0.01)$ in LDH where males showed higher level of LDH with an average of $415.77 \pm 90.35 \mathrm{mg} / \mathrm{dL}$ than females with an average of $348.34 \pm 42.26 \mathrm{mg} / \mathrm{dL}$. CEA was higher in males with an average CEA of $1.30 \pm 0.53 \mathrm{ng} / \mathrm{dL}$ in males and $1.04 \pm 0.13$ $\mathrm{ng} / \mathrm{dL}$ in females, showing a statistically significant difference between males and females $(p<0.01)$. On the other hand, there was a statistically significant difference in TSH level ( $p$ $<0.01)$ and CA19-9 $(p<0.05)$, where females showed higher level of TSH with an average of $2.75 \pm 1.35$ than males with an average of 1.92 1.04 , and higher level of CA19-9 with an average of $7.38 \pm 4.81$ than males with an average of $4.86 \pm 3.47$. There was no statistically significant difference in LDL cholesterol and CPK. The clinical laboratory results of the subjects are displayed in Table 2.

Table 3. Results of CIMT by gender

\begin{tabular}{ccccc}
\hline \multirow{2}{*}{ Variable } & $\begin{array}{c}\text { Total } \\
\mathrm{N}=67\end{array}$ & $\begin{array}{c}\text { Male } \\
\mathrm{N}=35\end{array}$ & $\begin{array}{c}\text { Female } \\
\mathrm{N}=32\end{array}$ & \multirow{5}{*}{$\mathrm{F} / \mathrm{t}$} \\
\cline { 2 - 4 } & \multicolumn{5}{c}{$\mathrm{M} \pm \mathrm{SD}$} \\
\hline CIMT (mm) & $0.51 \pm 0.06$ & $0.53 \pm 0.54$ & $0.47 \pm 0.65$ & $0.73 / 4.07^{\dagger}$
\end{tabular}

Abbreviation: CIMT, carotid intima media thickness. ${ }^{*} p<0.05,{ }^{\dagger} p<0.01$.

\section{CIMT test results by gender}

The average total CIMT was $0.51 \pm 0.06 \mathrm{~mm}$, and males and females showed a statistically significant difference $(p<0.01)$, where males showed an average of $0.06 \mathrm{~mm}$ thicker CIMT than females with an average of $0.53 \pm 0.54 \mathrm{~mm}$ in males and $0.47 \pm 0.65 \mathrm{~mm}$ in females. The CIMT test results by the gender of the subjects are displayed in Table 3.

\section{CIMT test results by age}

According to the CIMT test results by age, the 30's group showed an average of $0.47 \pm 0.05 \mathrm{~mm}, 40$ 's an average of $0.50 \pm 0.06 \mathrm{~mm}$, and 50's an average of $0.54 \pm 0.06 \mathrm{~mm}$. The analysis of variance $F$-value appeared as 3.86 , showing difference in variation. The 40's group showed a tendency of higher CIMT test result than the 30's group, but there was no significant difference between the groups. The 50's group showed a tendency of higher CIMT test result than the 40's group, but there was also no significant difference between the groups. The 50's showed an average of $0.07 \mathrm{~mm}$ higher value than that of 30's group, and displayed a statistically significant difference $(p<0.05)$ in CIMT test results between the groups. The CIMT test results by the age of the subjects are displayed in Table 4.

\section{Correlation between carotid artery ultrasonography, clinical laboratory test results, and general characteristics}

According to an analysis of the correlation between the results from the carotid artery ultrasonography, each variable of the general characteristics of the subjects, and results from the blood test, the results of carotid artery ultrasonography and CIMT showed a positive correlation with general characteristics, where age group showed a positive relationship ( $p$

Table 4. Results of Carotid Artery Ultrasonography by age

\begin{tabular}{|c|c|c|c|c|c|}
\hline \multirow[t]{2}{*}{ Variable } & $\begin{array}{c}\text { 30s group } \\
N=8\end{array}$ & $\begin{array}{c}\begin{array}{l}\text { 40s group } \\
\mathrm{N}=42\end{array}\end{array}$ & $\begin{array}{l}\text { 50s group } \\
\quad N=17\end{array}$ & \multirow[t]{2}{*}{$F / p$} & \multirow[t]{2}{*}{ Dunnett T3 } \\
\hline & & $M \pm S D$ & & & \\
\hline CIMT (mm) & $0.47 \pm 0.05$ & $0.50 \pm 0.06$ & $0.54 \pm 0.06$ & $3.86 / 0.02$ & $a<c^{*}$ \\
\hline
\end{tabular}

Abbreviations are the same as those in Table 3. ${ }^{*} p<0.05$. 
Table 5. Correlation of carotid artery ultrasonography, blood test and general characteristics

\begin{tabular}{|c|c|c|c|c|c|c|c|c|c|}
\hline & CIMT & Age & Height & Weight & SBP & ALT & GGT & Uric acid & CEA \\
\hline CIMT (mm) & 1 & $.400^{\dagger}$ & $.456^{\dagger}$ & $.400^{\dagger}$ & $.270^{\star}$ & $.259^{\star}$ & $.278^{*}$ & $.285^{\star}$ & $.286^{*}$ \\
\hline Age & & 1 & -.022 & .098 & .217 & $.251^{\star}$ & $.296^{*}$ & $.282^{\star}$ & -.067 \\
\hline Height $(\mathrm{cm})$ & & & 1 & $.799^{\dagger}$ & $.322^{\dagger}$ & $.247^{\dagger}$ & $.361^{\dagger}$ & $.513^{\dagger}$ & .398 \\
\hline Weight (kg) & & & & 1 & $.348^{\dagger}$ & $.397^{\dagger}$ & $.409^{\dagger}$ & $.601^{\dagger}$ & .240 \\
\hline $\mathrm{SBP}(\mathrm{mmHg})$ & & & & & 1 & $.323^{\dagger}$ & $.455^{\dagger}$ & $.316^{\dagger}$ & $.344^{\dagger}$ \\
\hline ALT (IU) & & & & & & 1 & $.518^{\dagger}$ & $.517^{\dagger}$ & .155 \\
\hline GGT (IU) & & & & & & & 1 & $.252^{\star}$ & $.283^{*}$ \\
\hline Uric acid (mg/dL) & & & & & & & & 1 & $.289^{*}$ \\
\hline CEA (mg/dL) & & & & & & & & & 1 \\
\hline
\end{tabular}

Abbreviations are the same as those in Table 1, 2, 3.

${ }^{*} p<0.05,{ }^{\dagger} p<0.01$.

$<0.01$ ). For physical characteristics, height and weight both showed a positive relationship ( $p<0.01$ ), and systolic blood pressure also displayed a positive relationship $(p<0.05)$. ALT, GGT, Uric acid, and CEA all showed a positive correlation ( $p$ $<0.05$ ) with the clinical laboratory blood test. The correlation between results of the carotid artery ultrasonography and each variable is displayed in Table 5 .

\section{Discussion}

The purpose of this study was to investigate the correlation between CIMT by the carotid artery ultrasonography and clinical laboratory test, which is part of the blood test item in a physical examination category that is generally being conducted. The clinical laboratory blood test and CIMT test results analyzed in this study was conducted at a large comprehensive health examination center located in Gyeonggido. The subjects of this study were 67 healthy adults in the age of $30 \sim 55$, with 35 males and 32 females. The age distribution of the subjects was 8 in the 30's group, 42 in the 40's group, and 17 in the 50's group, with the 40's group displaying the

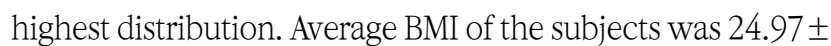
2.30 in males and $24.17 \pm 12.05$ in females, showing no difference between the male and female group. There was a statistically significant difference $(p<0.01)$ in systolic blood pressure with an average of $120.34 \pm 13.96 \mathrm{mmHg}$ in males and $108.47 \pm 12.51 \mathrm{mmHg}$ in females. The average diastolic blood pressure in males was $81.43 \pm 9.61 \mathrm{mmHg}$ and $70.97 \pm 10.31 \mathrm{mmHg}$ in females, showing a significant difference $(p<0.01)$ in diastolic blood pressure level. Hyper- tension is a risk factor of cardiovascular disease (O Donnell C) et al., 1997) and blood pressure is associated with CIMT (Pall et al., 2003). In this study, systolic blood pressure showed a positive relationship with CIMT ( $p<0.01$ ), as well as with age $(p<0.01)$. These results are shown in the results that the thickness of the carotid artery increases with age is increased CIMT (Veller et al., 1993). These results correlate with results from previous studies that reported an association of age and systolic pressure with CIMT (Urbina et al., 2002). This may be due to the small number of subjects investigated in this study (Park et al., 2005). However, different from the results of previous studies that reported CIMT measured by a carotid artery ultrasonography as an independent indicator for predicting risk factors of atherosclerosis, cardiovascular disease, and myocardial infarction, there was no significant correlation between CIMT and risk factors for cardiovascular disease, such as total cholesterol, HDL cholesterol, LDL cholesterol, and triglyceride level (Pearson, 2002). This may be due to the small number of subjects investigated in this study (Bae et al., 2005).

In conclusion, this study investigated the correlation between CIMT and clinical laboratory test results, in addition to the relationship between CIMT and blood pressure and cardiovascular risk factors that was previously studies. Results of this study showed that CIMT has a positive correlation with ALT $(p<0.05)$, GGT $(p<0.05)$, Uric acid ( $p<$ $0.05)$, and CEA $(p<0.05)$, and therefore further studies should be considered for continuous investigation. 


\section{요 약}

경동맥 내중막 두께는 뇌혈관질환과 관상동맥질환을 정밀하게 측정하는 검사이다. 많은 선행논문에 따르면 경동맥 내중막 두께는 죽상동맥경화를 예측하고 심혈관질환의 위험인자와 연관성이 높 으며, 심근경색이나 뇌졸중 발생 위험을 예측할 수 있는 독립인자 로 연구되었다. 따라서 본 연구는 혈액검사 중 임상화학적 검사결 과와의 상관관계 연구를 통해 경동맥 내중막 두께와 다른 독립인자 를 확보하는 것이 목적이었다. 연구결과 피험자의 부족으로 인해 심혈관계관련 임상화학적 요인과는 상관관계를 입증하지 못했으 나, 경동맥 내중막 두께와 ALT $(p<0.05), \operatorname{GGT}(p<0.05)$, Uric $\operatorname{acid}(p<0.05), \mathrm{CEA}(p<0.05)$ 와 양의 상관관계를 통계적인 유의 수준으로 입증하여 지속적인 연구의 문제를 제기하였다.

Acknowledgements: This study was financially supported by Dongnam Health University.

Funding: None

Conflict of interest: None

\section{References}

1. Bae JH, Seung KB, Jung HO, Kim KY, Yoo KD, Kim CM, et al. Analysis of korean carotid intima-media thickness in korean healthy subjects and patients with risk factors: Korea multi-center epidemiological study. Korean Circulation J. 2005, 35:513-524.

2. Burke G, Evans G, Riley W, George H, Barnes RW, Crow RS, et al. Arterial wall thickness is associated with prevalent cardiovascular disease in middle aged adults. The atherosclerosis risk in communities (ARIC) study. Stroke. 1995, 26:386-391.

3. Chambless LE, Heiss G, Folsom AR, Rosamond W, Szklo M, Sharrett AR, et al. Association of coronary heart disease incidence with carotid arterial wall thickness and major risk factors: The atherosclerosis risk in communities (ARIC) study, 1987-1993. Am J Epidemiol. 1997, 146(6):483-494.

4. Freedman DS, Dietz WH, Tang R, Mensah GA, Bond MG, Urbina EM. The relation of obesity throughout life to carotid intima-media thickness in adulthood: The bogalusa heart study. int J Obes Relat Metab Disord. 2004, 28:159-166.

5. O Donnell CJ, Ridker PM, Glynn RJ, Berger K, Ajani U, Manson JE, et al. Hypertension and borderline isolated systolic hypertension increase risks of cardiovascular disease and mortality in male physicians. Circulation. 1997, 95(5): 1132-1137.

6. Park KO, Choi SJ, Yeom HH, Chung SH, Yu JJ, Park YS, et al. Carotid Intima-Media Thickness Measurement in Obese Children. Korean Journal of Pediatrics. 2005, 48(9):1738-1061.

7. Pall D, Settakis G, Katona E, et al. Increased common carotid artery intima media thickness in adolescent hypertension. Cerebrovasc Dis. 2003, 15:167-172.

8. Pearson TA. New tools for coronary risk assessment: what are their advantages and limitations? Circulation. 2002,105(7):886892.

9. Salonen R, Salonen JT. Progression of carotid atherosclerosis and its determinants a population-based ultrasonography study. Atherosclerosis. 1990, 81:33-40.

10. Sung HH. The correlation between BMI and chemistry test results in adult women. Bulletin of Dongnam Health University. 2014(1), 32:63-67.

11. Urbina EM, Srinivasan SR, Tang R, Bond MG, Kieltyka L, Berenson GS. Impact of multiple coronary risk factors on the intima-media thickness of different segments of carotid artery in healthy young. Am J Cardiol. 2002, 90:953-958.

12. Veller MG, Fisher CM, Nicolaides AN, RentonS, GeroulakosG, Stafford NJ, et al. Measurementof the ultrasonic in-tima-media complex thickness in normal subjects. J Vasc Surg. 1993, 17:719-25. 